Analysis

\title{
Valuing biodiversity enhancement in New Zealand's planted forests: Socioeconomic and spatial determinants of willingness-to-pay
}

\author{
Richard T. Yao a,*, Riccardo Scarpa b,f , James A. Turner ${ }^{c}$, Tim D. Barnard a , John M. Rose ${ }^{\text {, }}$ \\ João H.N. Palma ${ }^{\mathrm{e}}$, Duncan R. Harrison ${ }^{\mathrm{a}}$
}

a Scion (NZ Forest Research Institute Ltd.), Private Bag 3020, Rotorua, New Zealand

b Department of Economics, University of Waikato, Private Bag 3105, Hamilton, New Zealand

c AgResearch Ltd., Private Bag 3123, Hamilton, New Zealand

d The University of Sydney, NSW 2006, Australia

e Instituto Superior de Agronomia, Universidade de Lisboa, Portugal

${ }^{\mathrm{f}}$ Gibson Institute, School of Biological Sciences, Queens University Belfast, United Kingdom

\section{A R T I C L E I N F O}

\section{Article history:}

Received 29 June 2012

Received in revised form 9 December 2013

Accepted 16 December 2013

Available online 24 January 2014

\section{Keywords:}

Planted forests

Biodiversity

Discrete choice experiment

Willingness to pay

Random parameters logit

Ordinary least squares panel regression

\begin{abstract}
A B S T R A C T
Planted forests are increasingly recognised for the provision of habitats for species threatened with extinction Despite this development, a limited number of empirical studies have been undertaken to estimate the economic value of this ecosystem service. New Zealand's planted forests provide habitat to at least 118 threatened species. These forests can be managed to increase the abundance of many of these species. We present findings from survey data obtained in a discrete choice experiment designed to estimate the non-market values for a proposed biodiversity enhancement programme in New Zealand's planted forests. We used a two-stage modelling process. First we estimated the individual specific willingness to pay values and then we explored their socio-economic and spatial determinants. The first stage modelling process, which used a random parameters logit model with error components, suggested that willingness to pay was higher for increasing the abundance of native bird than for non-bird species. The second stage model used a least squares panel random-effects regression. Results from this method suggested that socioeconomic characteristics, such as attitudes toward the programme and distance from large planted forests, influenced willingness to pay for biodiversity enhancement.
\end{abstract}

(c) 2013 Elsevier B.V. All rights reserved.

\section{Introduction}

Planted forests are defined as a type of land use "composed by trees established through planting or seeding by human intervention" by the Food and Agriculture Organisation (FAO, 2012a). The world's 264 million hectares of planted forest account for seven percent of the global forest area (FAO, 2010). A planted forest can host a single or many natural and/or exotic forest species. Allocation of land for planted forests is generally undertaken for commercial reasons such as to address demand for roundwood, pulp, non-wood products and other forest goods (Bauhus et al., 2010). Planted forests also contribute to conservation of natural forests by off-setting pressure on primary and old growth forests (Dyck, 2003; UNCED, 1992). In addition, planted forests provide ecosystem services that include water quality improvement,

\footnotetext{
The opinions provided in the paper have been provided in good faith and on the basis that every endeavour has been made to be accurate and not misleading and to exercise reasonable care, skill and judgement.

* Corresponding author. Tel.: + 647343 5747; fax: + 6473480952.

E-mail addresses: richard.yao@scionresearch.com (R.T. Yao),

rscarpa@mngt.waikato.ac.nz (R. Scarpa), james.turner@agresearch.co.nz (J.A. Turner), tim.barnard@scionresearch.com (T.D. Barnard), john.rose@sydney.edu.au (J.M. Rose), joaopalma@isa.ulisboa.pt (J.H.N. Palma), duncan.harrison@scionresearch.com (D.R. Harrison).
}

carbon sequestration and habitat provision for native species (including those threatened by extinction) (Brockerhoff et al., 2008; FAO, 2012b; Jukes et al., 2001; Pawson et al., 2010; Whittam et al., 2002; Yao et al., 2013). Planted forests can be managed to enhance the provision of habitat for rare and protected native species (Bauhus et al., 2010; Maunder et al., 2005; Pawson, 2005), but these benefits come at a cost (Alavalapati et al., 2002; Matta et al., 2009; Weir, 2010). Such benefits are difficult to define and to quantify. It is therefore important to examine if the general public would benefit, and by how much, from a biodiversity enhancement initiative. This study sets out to achieve this by conducting a nationwide choice experiment survey.

\subsection{Previous Studies}

Many studies have explored the links between forests, their biodiversity and the benefits derived from such biodiversity by the general public. Of these studies, some have examined how biodiversity enhancement affects the value derived by an individual from forest recreation. For example, Scarpa et al. (2000) applied contingent valuation (CV) and found that creating nature reserves in forests in Ireland, which contributes to preserving biodiversity, was significantly and positively associated with the economic welfare of forest visitors. This 
result is consistent with other empirical studies that also suggest forest biodiversity enhancement positively affects recreational choice; forests with higher levels of species diversity are preferred to those with lesser diversity (Boxall et al., 1996a; Dhakal et al., 2012; Hanley et al., 2002). Boxall and Macnab (2000) used a choice experiment (CE) and found that increasing the opportunity to see rare wildlife species in Canadian boreal forests was of significant additional value to wildlife viewers. Christie et al. (2007) employed a series of stated "choice experiments" alongside contingent behaviour methods and found that cyclists, horse riders, nature watchers and general forest recreationists would be willing to pay up to $£ 19$ per person per visit to support a proposed programme that would increase the opportunities to view wildlife in United Kingdom woodlands.

One criticism of the stated preference (SP) approach (which includes (E) is that it is based on a hypothetical market and respondents may deal with unfamiliar situations (Whitehead et al., 2011). For this reason, the development of a hypothetical market for the non-market good in question requires a rigorous scoping exercise prior to conducting the experiment. This exercise involves interviewing experts and conducting in-depth focus groups to objectively identify the attributes and carefully construct the valuation scenario. Although the market is hypothetical, the change in provision from the status-quo conditions to an improved level should be both ecologically feasible and perceived as realistic by respondents. The inclusion of cheap talk scripts, such as those developed by Cummings and Taylor (1999), has also been found to reduce hypothetical bias (Landry and List, 2007; Mozumder and Berrens, 2007). In terms of estimation of willingness to pay (WTP) values, Axsen et al. (2009) combined SP data with revealed preference (RP) data and estimated a model that imposes a greater weight on the SP data. They found this approach to produce more realistic WTP values as RP data tend to suffer from the econometric problem of multicollinearity.

The WTP for viewing or hearing forest wildlife species mainly applies to on-site forest users. In addition, some members of the general public would still be willing to pay for a biodiversity enhancement programme even though they are unlikely to visit forests. Some planted forests in New Zealand are situated on leased private land and public access to these is limited. However, even individuals who may not have access to the forest may still hold positive existence values (values placed on the existence of a resource) and bequest values (values from endowing biodiversity for future generations) for forest biodiversity (Freeman, 1993; Garrod and Willis, 1997; Meyerhoff et al., 2009; Sutherland and Walsh, 1985). In general, initiatives to conserve or enhance the abundance of species that are threatened by extinction are valued by the general public even when those who support these initiatives do not necessarily directly experience the outcomes (Meyerhoff et al., 2009).

Recent CE based environmental valuation studies have been linked primarily to ecosystem services. For instance, Tait et al. (2012) used CE data and a random parameters logit model to value water quality and quantity in the Canterbury region in New Zealand. Morse-Jones et al. (2012) applied CE to investigate the preferences of UK residents for conservation of charismatic and endemic species in Tanzania. Christie et al. (2006) used CE to examine a range of biodiversity policy attributes including familiarity of species, species rarity, habitat, and ecosystem processes. Travisi and Nijkamp (2008) used CE to examine if respondents would pay a premium price for agricultural products produced in environmentally benign ways, partly to conserve biodiversity in farmland ecosystems. This present study aims to extend these previous ecosystem valuation studies by using CE to examine the preferences of a sample of respondents toward improved habitat provision for key species in planted forests. Although planted forests in New Zealand are highly modified from their native counter-parts, they can still be managed to provide habitat for particular species. To keep our valuation scenario simple, we elected to focus on species that are likely to be familiar to respondents (e.g., brown kiwi). This study specifically focused on species abundance. Abundance is only one aspect of the complex concept of biodiversity, but an important one.

\subsection{New Zealand's Planted Forests and Biodiversity Values}

New Zealand has 1.72 million hectares of planted forest accounting for $22 \%$ of the country's total forest area (MPI, 2012). As of March 2011, planted forest products were one the country's major contributor to exports with a total value of NZ\$4.7 billion (3\% of GDP) (NZFOA, 2011). New Zealand's planted forests consist mainly of exotic tree species, with radiata pine (Pinus radiata) accounting for $90 \%$ of the total forest area, while the remaining species include Douglas-fir (Pseudotsuga menziesii), Cypresses (Cupresus spp.) and Eucalypts (Eucalyptus spp.) (MPI, 2012). Although these forests are intensively managed for timber production, many threatened species can still complete their life cycle in planted forest areas (Pawson et al., 2010).

Planted forests provide habitat for at least 118 threatened native species that include the brown kiwi (the country's national symbol) and the bush falcon (Pawson et al., 2010; Seaton et al., 2009). Areas in between clear-cut and remaining forest stands of the Kaingaroa forest in the Central North Island region provide bush falcon habitat that is better than any other area (Maunder, 2008; Seaton et al., 2009). The Kaingaroa forest has the highest concentration of bush falcon in the country (Stewart and Hyde, 2004). The presence of a mosaic of stands with different age profiles across this 185,000 -hectare forest provides falcons with suitable nesting sites and a plentiful supply of prey (Maunder, 2008; Seaton et al., 2010). Additional conservation activities could be undertaken with conservation groups. Such activities include increasing the frequency of monitoring of falcon nests and targeted pest control, which would help sustain and enhance falcon population in the forest (Maunder, 2008). New conservation activities would not only entail additional costs but are also likely reduce the number of trees that can be harvested, thereby reducing the sustainability of a forest business. For example, a five-year programme that could guarantee the establishment of a bush falcon population in a forest would cost approximately NZ\$100,000 to undertake (Yao et al., 2012).

Native plants and animals are highly valued by New Zealanders because they contribute to the culture and a sense of national identity (DOC, 2010). Native birds and plants can be seen all over the country, both in public conservation areas (e.g., national parks, forest parks) and private lands (e.g., planted forests). Using a dichotomous choice CV method, Yao and Kaval (2010) estimated that an average New Zealand resident would be willing to pay about NZ\$82 (in 2008 currency) per year in additional local taxes to support the planting of more native trees and shrubs on public land and NZ\$42 per year for more native plants on private land. Planting native trees and shrubs would provide additional habitat to native fauna such as birds, fishes and geckos. Although Yao and Kaval (2010) show that additional native trees are valued on private land, it remains unclear whether increasing the abundance of threatened native species in planted forests by improving habitats would be valued by New Zealanders, and if so how much it is valued.

\subsection{Research Questions and Structure of the Paper}

Adequate estimates of the benefits to New Zealanders of policies to enhance biodiversity in planted forests would provide insights and guidance to the implementation of the country's biodiversity programmes on private land. Many of these programmes are in line with New Zealand's 20-year Biodiversity Action Plan (2000 to 2020) (Ministry for the Environment, 2000a,b). This action plan encourages those government agencies concerned with biodiversity to establish partnerships with the private sector (e.g., forest companies) to manage biodiversity, which includes conservation of key threatened species (CAG, 2012; Ministry for the Environment, 2000a). Estimates of the value of the benefits from biodiversity enhancement will inform the formulation of future 
policies for the management of planted forests not only in New Zealand but also in other countries where similar conditions exist. Rather than simply derive benefit estimates, we wish to go a step further and explore the determinants of the variation within our sample of such estimates. We aim to answer the following questions in this study:

(1) Which factors influence individual WTP for biodiversity enhancement and by how much would these factors affect the individual WTP?

(2) Would an individual residing close (i.e., less than ten kilometres away) to large planted forests have a higher WTP for biodiversity enhancement compared to those living further away?

Answers to the above questions would be useful for the planning of biodiversity on private land. For forest managers, WTP estimates can be used to report on the value of enhanced biodiversity to the local community and the trade-offs in revenues from timber production and environmental values from forest management.

Section 2 describes the different approaches used in this study to estimate biodiversity values, the sampling approach and the construction of spatial data. Section 3 describes the econometric models and spatial methods used in the study. Section 4 provides a summary of the data collected. Section 5 presents the results of econometric analyses and interpretations of the estimated coefficients. The paper ends with conclusions and policy implications.

\section{Approaches to Valuing Biodiversity Enhancement}

\subsection{The Choice Experiment}

CE has been conducted in the field of environmental economics since the mid-1990s (Boxall et al., 1996b) to obtain indirectly data on the preference of individuals for changes in the provision of environmental goods. In a CE survey, a respondent is presented with a series of choice tasks that leads to the collection of a panel of choice responses. Each choice task contains a set of alternatives. Each set is described by several environmental attributes of relevance to the sample of respondents and a cost for each alternative in the choice task. The choice set usually includes a status quo (with attribute levels set at their current levels of provision) and experimentally designed alternatives (with attribute levels set at current and changed levels of provisions). When a respondent selects the preferred alternative (from among two or more alternatives), she implicitly reveals her trade-offs between the levels of attributes in all the alternatives shown in a choice task. A sample choice task used in this study is given in Fig. 1. In this study, each survey respondent was provided with nine choice tasks to evaluate. Each choice task had three alternatives and six attributes.

Of the six attributes in Fig. 1, five relate to environmental aspects and one to the cost of the proposed policy (expressed as dollar amounts per year). Each environmental attribute represents a threatened native species identified as important to New Zealanders. These species were
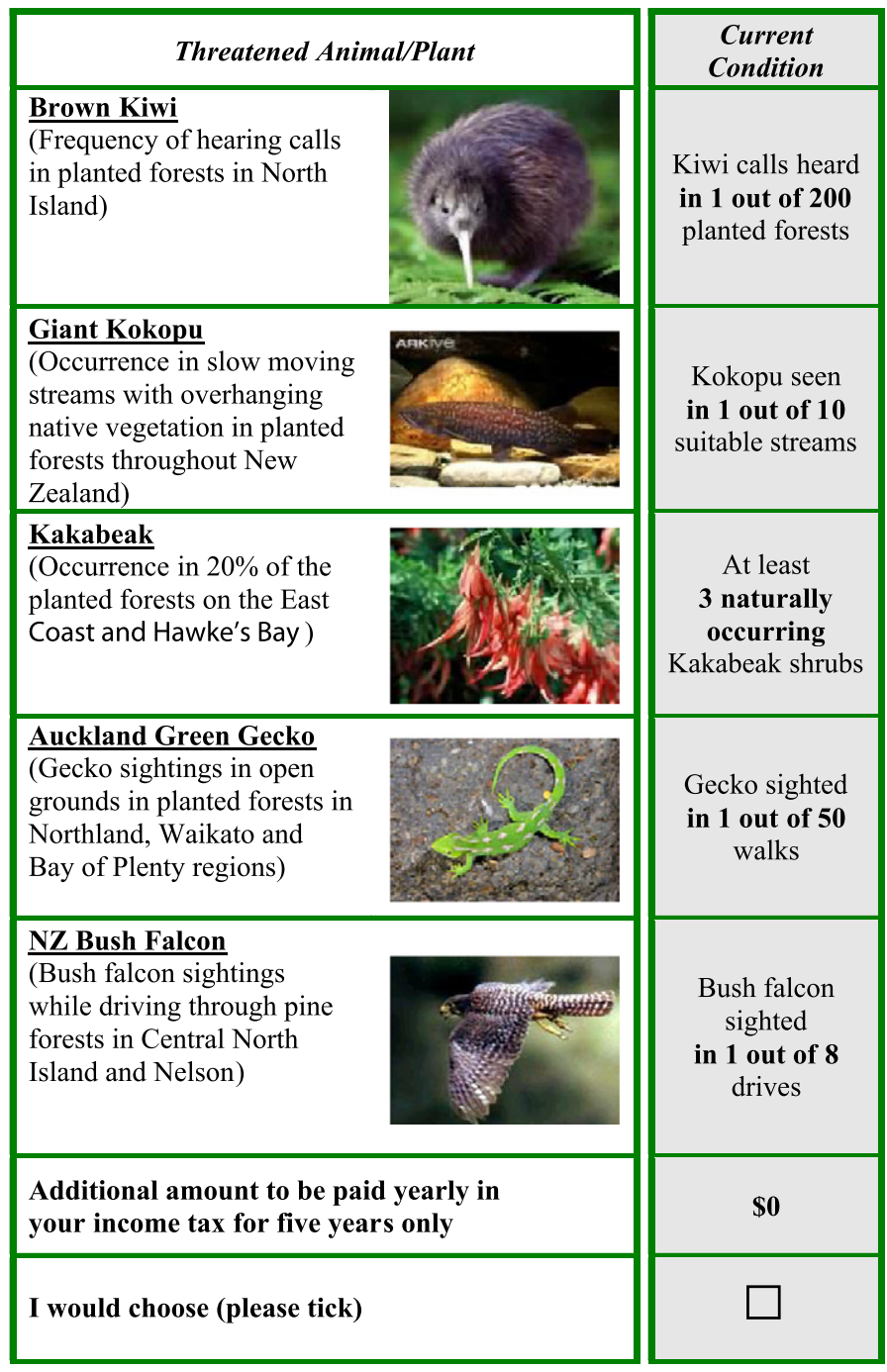

\begin{tabular}{|c|c|}
\hline Option I & Option $J$ \\
\hline $\begin{array}{l}\text { Kiwi calls heard } \\
\text { in } 1 \text { out of } 200 \\
\text { planted forests }\end{array}$ & $\begin{array}{c}\text { Kiwi calls heard } \\
\text { in } 20 \text { out of } 200 \\
\text { planted forests }\end{array}$ \\
\hline $\begin{array}{c}\text { Kokopu seen } \\
\text { in } 3 \text { out of } 10 \\
\text { suitable streams }\end{array}$ & $\begin{array}{l}\text { Kokopu seen } \\
\text { in } 1 \text { out of } 10 \\
\text { suitable streams }\end{array}$ \\
\hline $\begin{array}{c}\text { At least } \\
\mathbf{2 0} \text { actively } \\
\text { managed } \\
\text { Kakabeak shrubs }\end{array}$ & $\begin{array}{c}\text { At least } \\
\mathbf{3} \text { actively } \\
\text { managed } \\
\text { Kakabeak shrubs }\end{array}$ \\
\hline $\begin{array}{c}\text { Gecko sighted } \\
\text { in } 3 \text { out of } 50 \\
\text { walks }\end{array}$ & $\begin{array}{c}\text { Gecko sighted } \\
\text { in } 1 \text { out of } 50 \\
\text { walks }\end{array}$ \\
\hline $\begin{array}{l}\text { Bush falcon } \\
\text { sighted } \\
\text { in } 5 \text { out of } 8 \\
\text { drives }\end{array}$ & $\begin{array}{l}\text { Bush falcon } \\
\text { sighted } \\
\text { in } 1 \text { out of } 8 \\
\text { drives }\end{array}$ \\
\hline$\$ 30$ & $\$ 30$ \\
\hline & \\
\hline
\end{tabular}

Fig. 1. An example of a choice task used in the survey. 
selected based on a series of four focus group meetings with a variety of stakeholders (see Yao, 2012 for details). The species included were the bird brown kiwi (Apteryx mantelli), ${ }^{1}$ the fish giant kokopu (Galaxias argenteus), the plant kakabeak (Clianthus maximus), the lizard green gecko (Naultinus elegans elegans) and the bird bush falcon (Falco novaeseelandiae) (Fig. 2). Each attribute was described using three levels of species abundance that can be supported by planted forests, as advised by ecologists and forest managers. The base level represents the current level of abundance. From the current condition, we identified a feasible expansion to an intermediate level of improvement (Level 1) and to a higher level still (Level 2). Adequate levels of a "realistic" payment over a period of five years were identified from two focus groups as $\$ 30, \$ 60$ and $\$ 90$. The survey was constructed then was tested on a test group of 10 respondents at the location of the study. These respondents represented a small sample of the population likely to be completing the survey. Respondents were asked to complete the survey, and then were asked a series of questions regarding the ease of completing the survey and clarity of the survey questions. Adjustments were made accordingly to finalise the survey instrument.

Before showing the actual valuation questions in the questionnaire, we provided each respondent with an overview of the location and the current situation of the species in the choice task (Fig. 3). After this overview, we described the proposed biodiversity programme and presented a walk-through example of how one could select the preferred alternative in each choice task (an instruction choice task). In the valuation scenario, we included a "cheap talk" script as recommended by Cummings and Taylor (1999). Some of the reasons for including the script are to specifically draw the respondent's attention to the cost variable and to remind respondents that they could use their money to buy other things they enjoy (Cameron et al., 2011). The script also includes statements that made clear the consequentiality of the survey (Vossler et al., 2012). The cheap talk script seen by respondents is presented in Appendix A.

After the warm up exercise, the valuation scenario was presented. In the valuation scenario, it was mentioned that payment for the biodiversity programme will be paid via income tax annually for five years. ${ }^{2}$ The payment amount will be forwarded to the Department of Conservation (DOC) who will coordinate with forestry companies and other concerned organisations to undertake the proposed programme. ${ }^{3}$ Respondents were then asked to evaluate a series of nine choice tasks.

\subsection{Experimental Design}

In $\mathrm{CE}$, experimental design criteria are used to generate the different choice tasks for the indirect valuation of the environmental good in question. Several design criteria have been developed (Burgess and Street, 2005; Scarpa and Rose, 2008). Designs generated using different criteria vary mainly in terms of statistical properties, which include orthogonality and efficiency (Rose et al., 2011).

In this present study, we employed a sequential experimental design by administering the survey in two waves following Scarpa et al.

\footnotetext{
${ }^{1}$ Brown kiwis are nocturnal birds. People would not necessarily expect to see a kiwi in the wild but appreciate hearing a kiwi call.

2 We chose income tax because biodiversity conservation is a pure public good and as such it should be funded by the central government. We realise that in our sample the fraction of respondents not income paying taxes is higher than the NZ average. We assume that for most this is only a temporary and not a permanent condition over the five year period that the payment is hypothesized for. As such the incentive compatibility of this payment vehicle should not have been seriously affected.

${ }^{3}$ We developed this hypothetical market based on consultations with key staff members of the Department of Conservation, forest managers and focus group participants. The market was designed to allow respondent's utility be affected by the different levels of biodiversity outcomes for them to truthfully select the preferred alternative in each choice task. These, plus the inclusion of a cheap talk script, represented our best effort towards inducing respondents in our hypothetical market to provide us with truth revealing WTP responses (DOI (Department of the Interior) (1994) as cited by Harrison (2006)). This is in line with the current state of survey practice in non-market valuation.
}

(2007a) and Kerr and Sharp (2010). An orthogonal main effects design was used for the first wave of 35 respondents. This initial design was used as we did not have prior knowledge about the values of the indirect utility coefficients. Data collected from the first wave were used to estimate the parameters of a multinomial logit model (Appendix B). Estimates of utility coefficients and corresponding standard errors were used to generate three new experimental designs. All three designs were Bayesian efficient designs but each optimised a different criterion (D-efficiency, C-efficiency and S-efficiency) using the design software NGENE (ChoiceMetrics, 2011). We also generated a fourth design, i.e., an optimal orthogonal design, also designed using NGENE. A priori values were not used in the fourth design because this assumes that the utility coefficients are all zeroes. The four new experimental designs were used to construct the choice tasks for the second wave of the survey. As can be expected, experimental designs for the second wave had higher design efficiency compared to the orthogonal design (base design). Comparing the design efficiency to the base orthogonal design, the Bayesian D-efficient design improved by $8.4 \%$ in terms of Bayesian D-error while the optimal orthogonal improved by $11.4 \%$ in terms of $D_{z}$-error (Yao, 2012). Details about the methods for evaluating design efficiency can be found in Scarpa et al. (2007) and Scarpa and Rose (2008).

To the best of our knowledge, there is no study yet that examines the impact of using a combination of the experimental designs used in this study. However, we can assume that the impact of using such mixture of designs on the estimates would be minimal because each design might tend to offset its impact on the other given the difference in optimisation criterion (e.g., Bayesian D-efficiency, orthogonality). Perhaps a future study that evaluates the impacts of such mixture of designs would shed light on this issue.

\subsection{Sampling Frame, Survey Method and Choice Survey Sample}

We employed a stratified sampling approach based on the distribution of the population. In 2006, 92\% of New Zealand households had land based telephones (SNZ, 2011). We employed a combined phonemail and phone-internet survey approach. With this two-stage survey technique we first called people listed in the phone book and asked if they were interested in participating in a survey and then collected their survey response in the mode they preferred, internet or mail. Three survey assistants with native accent were employed to randomly call by phone and invite people to take part. Since a large majority of respondents indicated interest in completing the survey by mail, a decision was made relatively early on to focus mainly on surveys collected by phonemail. A total of 2996 phone calls were made between December 2009 and August 2010. About 781 people (26\% of the numbers called) agreed on the phone to participate in the survey. The final sample consisted of 261 completed surveys (33\% of the surveys sent) of which $84 \%$ were collected via mail and $16 \%$ online. ${ }^{4}$ Of the completed surveys, 209 survey respondents provided valid responses for the CE questions and their responses to our debriefing questions did not show any sign of protest. Of the 52 respondents (261 minus 209) who did not evaluate the choice questions, 17 appeared to have protested on how the questionnaire was designed. Statistics New Zealand reports that the ratio of urban to rural households in 2006 was 72 (urban) to $28 \%$. Due to our low response rate, we were unable to match exactly these sample proportions. In the final sample, the ratio was 60:40.

\footnotetext{
${ }^{4}$ A second stage response rate of $33 \%$ (261 out of the 781 survey sent). This is very low compared to the phone-mail survey of Yao and Kaval (2010) which had a second stage response rate of $88 \%$ ( 709 out of the 803 survey sent). However, low survey response rates were also experienced in other surveys such as Johnston and Roheim (2006) with $31 \%$ and Wordsworth et al. (2006) with 32\%, and Chen et al. (2010) with 29\%.
} 


\begin{tabular}{|c|c|c|c|}
\hline Threatened Animal/Pla & $\begin{array}{c}\text { Current } \\
\text { Condition }\end{array}$ & Level 1 & Level 2 \\
\hline Brown Kiwi & $\begin{array}{l}\text { Kiwi calls heard } \\
\text { in } 1 \text { out of } 200 \\
\text { planted forests }\end{array}$ & $\begin{array}{l}\text { Kiwi calls heard } \\
\text { in } 10 \text { out of } 200 \\
\text { planted forests }\end{array}$ & $\begin{array}{l}\text { Kiwi calls heard } \\
\text { in } 20 \text { out of } 200 \\
\text { planted forests }\end{array}$ \\
\hline Giant Kokopu & $\begin{array}{l}\text { Kokopu seen } \\
\text { in } 1 \text { out of } 10 \\
\text { suitable streams }\end{array}$ & $\begin{array}{c}\text { Kokopu seen } \\
\text { in } 3 \text { out of } 10 \\
\text { suitable streams }\end{array}$ & $\begin{array}{l}\text { Kokopu seen } \\
\text { in } 5 \text { out of } 10 \\
\text { suitable streams }\end{array}$ \\
\hline Kakabeak & $\begin{array}{c}\text { At least } \\
3 \text { naturally } \\
\text { occurring } \\
\text { Kakabeak shrubs }\end{array}$ & $\begin{array}{c}\text { At least } \\
\mathbf{1 0} \text { actively } \\
\text { managed } \\
\text { Kakabeak shrubs }\end{array}$ & $\begin{array}{c}\text { At least } \\
\mathbf{2 0} \text { actively } \\
\text { managed } \\
\text { Kakabeak shrubs }\end{array}$ \\
\hline $\begin{array}{l}\text { Auckland Green } \\
\text { Gecko }\end{array}$ & $\begin{array}{c}\text { Gecko sighted } \\
\text { in } 1 \text { out of } 50 \\
\text { walks }\end{array}$ & $\begin{array}{c}\text { Gecko sighted } \\
\text { in } 3 \text { out of } 50 \\
\text { walks }\end{array}$ & $\begin{array}{l}\text { Gecko sighted } \\
\text { in } 5 \text { out of } 50 \\
\text { walks }\end{array}$ \\
\hline NZ Bush Falcon & $\begin{array}{l}\text { Bush falcon } \\
\text { sighted } \\
\text { in } 1 \text { out of } 8 \\
\text { drives }\end{array}$ & $\begin{array}{l}\text { Bush falcon } \\
\text { sighted } \\
\text { in } \mathbf{3} \text { out of } 8 \\
\text { drives }\end{array}$ & $\begin{array}{l}\text { Bush falcon } \\
\text { sighted } \\
\text { in } 5 \text { out of } 8 \\
\text { drives }\end{array}$ \\
\hline
\end{tabular}

Fig. 2. The five native species with the current and proposed levels of provision.

\subsection{Determinants of WTP}

Our study examines the effects of the location of residence of respondents with respect to large planted forests, which can be found in many different areas of New Zealand. We tried to locate the geo-referenced spatial coordinates of respondent's place of residence. Respondents' existing addresses in the database were first verified using New Zealand Post's address-postcode-finder. Once confirmed, specific latitude and longitude coordinates for all addresses were found using the web site http://stevemorse.org/jcal/latlon.php which uses GoogleMaps to identify coordinates. ${ }^{5}$ Spatial coordinates of several online respondents were not located because of the absence of accurately verified addresses (e.g., their addresses were incomplete in the phone directory). Of the 209 respondents who provided valid choice observations, we located spatial coordinates of 115 respondents.

Given that there are multiple sites with large planted forests, we developed a method where the geo-spatial coordinate of each respondent was used to create geographical zones with radius of 10-, 50and 100-kilometre using ArcMap 10 and the programming language Python 2.6. The 10-, 50- and 100-kilometre zones were chosen to respectively represent biking distance, one-day trip and at the border of a one day trip to the planted forest of interest. Using a second digital layer that contains the New Zealand Land Cover Database version 2 (Ministry for the Environment, 2011), each zone was intersected with the sum of the area of planted forests, thus enabling the identification

\footnotetext{
5 More information regarding how we derived spatial coordinates (latitude and longitude coordinates) which include additional websites can be provided upon request to richard.yao@scionresearch.com.
}

of planted forest areas around each geo-spatial coordinate. A further step was taken to consider that threatened native species could only establish themselves in large forests. Native species, especially native birds, benefit more from larger forests. The New Zealand bush falcon benefits from a mosaic of forest plots of different ages (Seaton, 2007). To form such landscape, we have assumed that a large planted forest to be at least 5000 ha, such as those that can be found in New Zealand's Central North Island region, that provide habitats for many native bird species. To determine those large forest areas, contiguous planted forests of more than 5000 ha were aggregated and all the other scattered forests were ignored, and this procedure created the final set of zones or spatial intersections. We used the area of large planted forests derived from spatial intersections to create the spatial zone variables that we used as spatial covariates in the panel least squares regression model. We also included other covariates from the survey data such as socioeconomic characteristics, attitudes, and affiliation to conservation organisations to further explain the variation in individual specific WTPs.

\section{Models}

\subsection{Random Parameters Logit Model}

Random parameters logit (RPL) models (also known as mixed logit models) provide a computationally practical and flexible econometric approach to the analysis of discrete choices. It is based on random utility maximisation, but does not suffer from a series of restrictive behavioural assumptions (McFadden and Train, 2000). It is now well documented that RPL models overcome limitations of the basic conditional logit model (Hensher and Greene, 2003; Revelt and Train, 1998; Train, 2009). Under the RPL approach, the unobserved portion of utility is partitioned into two additive terms. A first one is heteroskedastic and 


\begin{tabular}{|c|c|}
\hline & $\begin{array}{l}\text { Brown Kiwi } \\
\text { Throughout New Zealand, the brown kiwi population has been declining at a rate of } \\
5 \% \text { per year, which implies their population halves every decade. Conservation } \\
\text { initiatives have started to ensure that the brown kiwi continues to live in a few exotic } \\
\text { forests. They can be found in planted forests in Northland, Coromandel, Central } \\
\text { North Island, Bay of Plenty and Hawke's Bay that also contain remnants of native } \\
\text { trees, stream edges with trees, clearfell and stands of various ages. The brown kiwi is } \\
\text { nocturnal and can be heard calling after dark. }\end{array}$ \\
\hline & $\begin{array}{l}\text { Native Fish } \\
\text { The giant kokopu is a rare native fish whose populations are gradually declining } \\
\text { throughout New Zealand. They can be found in suitable waterways in planted forests } \\
\text { in Bay of Plenty, East Coast, Waikato, southern North Island, West Coast and } \\
\text { Southland. They can be seen at night in gently flowing streams with overhanging } \\
\text { native vegetation. }\end{array}$ \\
\hline & $\begin{array}{l}\text { Native Shrub } \\
\text { The kakabeak is a widely cultivated shrub, however, natural populations are extremely } \\
\text { rare in the wild. Kakabeak has been found in planted forests on the East Coast and } \\
\text { Hawke's Bay, where they are found in stream edges with trees and in steep gullies. }\end{array}$ \\
\hline & $\begin{array}{l}\text { Native Lizard } \\
\text { Populations of the Auckland green gecko are in gradual decline. Populations have } \\
\text { been found in planted forests in Northland, Waikato and Bay of Plenty regions. They } \\
\text { have well developed vocal cords and can bark or chirp by clicking their tongues against } \\
\text { the roof of the mouth. They can be seen in tree branches, foliage and open ground. } \\
\text { Although they hunt by night for insects, they also like to sunbathe. }\end{array}$ \\
\hline & $\begin{array}{l}\text { NZ Bush Falcon } \\
\text { The NZ bush falcon is classified as vulnerable to extinction. Very few bush falcons } \\
\text { can be sighted on native bush but many can be found in large planted forests in North } \\
\text { Island which include Kaingaroa Forest in the Central North Island and in South } \\
\text { Island planted forests including the Golden Downs in Nelson. They can be sighted in } \\
\text { forest stand edges between clearfell and mature stands. }\end{array}$ \\
\hline
\end{tabular}

Fig. 3. Location and situation of the five native species in the choice task.

correlated over alternatives $(\eta)$ while the other is i.i.d. over alternatives $(\varepsilon)$ as showed in Eq. (1)

$U_{\mathrm{njs}}=\beta_{k} X_{\mathrm{nkjs}}+\eta_{\mathrm{nk}} X_{\mathrm{nkjs}}+\varepsilon_{\mathrm{njs}}$

where $\eta$ is the idiosyncratic random deviation of respondent $n$ from the mean population value of the taste coefficient of attribute $k ; j$ denotes the alternative; $s$ denotes the choice tasks; epsilon is the unobservable component of utility, which is assumed to be an i.i.d. Gumbel distributed random term (Hensher and Greene, 2003). The $\eta$ may be assumed to have a particular distribution postulated a priori. Frequently used distributions include normal, lognormal, truncated normal, triangular, Weibull and exponential. Assuming normal and lognormal distributions can be problematic as the former is sensitive to having some respondents with "theoretically invalid" signs (e.g., positive cost coefficient) while the latter exhibits a long tail (Train and Weeks, 2005). These properties are relevant to the current study of valuing biodiversity enhancements where taste intensities (or attribute coefficients) are expected to be positive for various improvements from the status quo. We employed an RPL model with panel specification that facilitates the estimation of the conditional means of the implied WTP distributions for each respondent (Train, 2009).

Although the basic RPL model, as mentioned above, accounts for heterogeneity in the sample, it still does not account for the effects of correlation between the two designed alternatives in the choice task. Respondents may consider the status-quo alternative in a systematically different manner from designed alternatives, because the status-quo alternative is experienced while the designed alternatives are hypothetical (Scarpa et al., 2005) and therefore only conjectured, especially when unfamiliar. The utilities derived from the designed alternatives would hence likely be more correlated between themselves than the utilities derived from a changed alternative and the status-quo alternative. This correlation structure can be accounted for by specifying a RPL model with additional errors that consider the difference in correlation across utilities (Herriges and Phaneuf, 2002). Specifying this RPL model with the additional error component addresses the status-quo bias (Haaijer, 1999; Haaijer et al., 2001; Hess and Rose, 2009; Samuelson and Zeckhauser, 1988) and state dependence (Hensher, 2008) effects. ${ }^{6}$

\subsection{Panel Data Regression of WTPS}

Campbell (2007) and Scarpa et al. (2011) have used panel random effects regression models to determine the factors influencing WTP for the improvement of environmental goods. This is a two-step validation method for testing the effects of socio-demographic covariates on individual WTPs. We employed this modelling approach because, in preference space utility specifications, WTP is a function of the coefficients of the cost attribute and other non-monetary attributes. Two individuals with different conditional parameter estimates can have the same estimated conditional mean WTP. As a result, a validity regression on conditional means is more likely to detect systematic effects of socioeconomic covariates on WTP variation than it is to detect these effects on random parameter estimates of the utility function. In fact, in many datasets, one fails to identify significant socio-economic covariates as

\footnotetext{
6 "Status-quo effect" is also referred to as "status-quo bias" in other papers. State dependence is defined by Hensher (2008) as "the influence of the actual (revealed) choice on the stated choices of the individual".
} 
taste parameter shifters, but then when one goes on to a second stage regression on individual WTPs, one finds significant socio-economic covariates effects on such conditional mean WTP estimates. For example, Scarpa and Thiene (2005) failed to identify any socio-economic variable to have an effect on membership probabilities in a latent class model of choice of destination for mountain visitation by climbers in the European Alps. However, when fitting a binary choice model to explain whether each climber was posterior-predicted to be a beneficiary from a certain policy, they found that number of trips to be highly significant and annual income to be nearly significant. Campbell (2007) also used a panel of individual specific means of the conditional distributions of marginal WTP values as the dependent variable, and socioeconomic characteristics and location as explanatory variables. His results suggested that income levels, community type and location significantly influence WTP. Similarly, Scarpa et al. (2011) used a panel of individual specific means derived from the conditional distributions of WTP as dependent variable and found socioeconomic characteristics (such as marital status or education level) explained reasonably well the variability in conditional means of marginal WTP. The above studies identified determinants of posterior WTP estimates from choice models in terms of socioeconomic characteristics and attitude of respondents, but none included distance of the respondents' places of residence from the public amenities under study.

While analyses of CE data that account for the spatial distributions of WTP estimates have been produced (Campbell et al., 2008, 2009; Concu, 2007), those that focused on the effects of distance from the source of externality on WTP represent a growing area of research in the SP literature (Garrod et al., 2002; Johnston et al., 2011; Rolfe and Windle, 2012; Schaafsma et al., 2012). Several CV studies have used distance-decay models and found that WTP is negatively associated with the distance of the individual from the environmental good in question (Bateman et al., 2000, 2006; Cameron, 2006; Hanley et al., 2003; Loomis, 1996; Mazur and Bennett, 2009; Sutherland and Walsh, 1985). However, Johnston et al. (2011) found no clear pattern of global distance decay on WTPs from a CE study because of the occurrence of noncontinuous spatial variation. Johnston identified the presence of WTP hotspots in a stated CE framework by applying the Getis-Ord statistic (Getis and Ord, 1992).

In this study, we derived the means of marginal WTP distributions for each respondent conditional on observed choice (see von Haefen, 2003 for details). As we used a choice task with five non-monetary attributes, with each having two improved levels, we had 10 conditional means (one for each attribute with random coefficient) per respondent. We wished to try and see how the variation of these WTP estimates can be explained on the basis of socio-economic characteristics of respondents, such as distance between place of residence and forests, taking into account the fact that these conditional means estimates are correlated when they pertain to the same respondent. So, we used a panel regression instead of the standard OLS regression and use it on the subset of respondents who provided us with the relevant socio-economic and spatial variables during the survey. We specify the panel regression as:

$W_{n a}=\alpha_{n}+\varphi A_{n a}+\psi R_{n}+\delta S_{n}+\varepsilon_{n a}$

where $W_{n a}$ represents a 10-period panel of WTP for attribute level $a$ for respondent $n, \alpha_{n}$ represents independent random variables with constant mean and variance, $A_{n a}$ is a vector of indicator variables for $k$ minus one attribute levels, $R_{n}$ represents a vector of socio-economic characteristics, attitude and affiliations of respondent $n, S_{n}$ is a vector of the natural log of areas of large planted forest included within a particular unit of radius from respondent $n$ (e.g., 10-kilometre radius, between 10- and 50-kilometre radius, between 50- and 100-kilometre radius), while $\varphi, \psi, \delta, \varepsilon$ are unknown parameters to be estimated. As a semi-log specification form is used for $W_{n a}$ and $S_{n}$, the estimated value of $\delta$ can be interpreted as the change in WTP due to a percentage change in area of large planted forests in that particular zone.

\section{Data}

Two data sets were used in the analysis. The first data set consisted of 1850 choice observations collected from 209 respondents across New Zealand. Almost all (98\%) of these respondents completed all nine choice tasks that they were presented with. This data set included the choice variable and choice attribute variables with panels of nine observations from respondents who completed all nine choice tasks. This was analysed using logit models. The second data set included a secondary variable with respondent-specific conditional means of marginal WTPs.

A summary of the socio-economic characteristics of the sample of respondents is given in Table 1. Our sample was biassed towards high income with $34 \%$ of the respondents having a household income above $\$ 100,000$. As a whole, only $22 \%$ of New Zealand's population had this level of income in 2006 (Statistics New Zealand, undated).

Forty-four percent of the respondents had tertiary or post-graduate education while $64 \%$ were women (Table 1 ). These proportions are slightly higher than the national proportions of $40 \%$ for higher education and $51 \%$ for women (Statistics New Zealand, undated). In terms of the sample proportion not in the labour force, this is also slightly higher (39\%) compared to the value reported in the national statistics (32\%). Only a small proportion of respondents reported they were volunteers in conservation organisations. One out of five of the respondents wanted to include the tui (Prosthemadera novaeseelandiae a popular non-threatened native bird) in the choice tasks. We asked respondents about their attitude toward supporting the proposed programme and found that $18 \%$ had the "Government-should-pay" attitude. This type of negative attitude is often labelled as a protest bid in the literature but it is not necessarily the case (Brouwer and Martin-Ortega, 2012). Our data indicate that five percent of the respondents who selected some non-status-quo alternatives also had the "Government Should Pay" attitude for the proposed programme. Respondents also rated their level of understanding of the choice questions after completing the nine choice tasks. Twenty-one percent of the respondents gave a rating of 10 indicating that only one out of five respondents completely understood the choice questions.

A summary of the spatial variables used as covariates in the OLS panel regression analysis is provided in Table 2. We located geospatially referenced coordinates of 115 respondents. Twenty eight of these (24\%) were less than $10 \mathrm{~km}$ away from one or more sections of large planted forest (with a contiguous size of at least $5000 \mathrm{ha}$ ). The sections of forest contained within each 10-kilometre zone range from 17 to 14,000 ha. Large planted forests are scattered throughout New Zealand. Therefore, someone residing within a 10-kilometre radius of a section of a large forest can also be within a 10-50-kilometre radius of another large forest (membership to forest zones is not mutually exclusive). Of the 28 respondents with forests less than $10 \mathrm{~km}$ away, 25 were also within the $10-50 \mathrm{~km}$ radius of another forest. Overall, about $71 \%$ of the respondents lived in areas situated 10 and $50 \mathrm{~km}$ from a large forest. Unsurprisingly, the sections of forest located in each 10-50 kilometre zone range from 1900 to 220,000 ha, given that the 10-50 kilometre zone covers a larger area than the $10-\mathrm{km}$ zone. The remainder of the respondents lived within 50-100 kilometre of a large planted forest.

\section{Results and Discussion}

\subsection{Logit Model Estimation}

Estimates from the random parameters logit (RPL) model with panel specification are presented in Table 3. This RPL model contains random parameters for selected attributes and for the status quo effect. The RPL model was estimated using 5000 Halton draws. The random parameters for selected attributes account for the fact that each respondent has a unique set of preferences for the attributes describing the proposed 
Table 1

Characteristics of respondents and the national proportion.

\begin{tabular}{|c|c|c|}
\hline Item & $\begin{array}{l}\text { Proportion of } \\
\text { respondents (\%) }\end{array}$ & $\begin{array}{l}\text { National } \\
\text { proportion }(\%)\end{array}$ \\
\hline \multicolumn{3}{|l|}{ Household income range } \\
\hline$\$ 20,000$ or less & 9 & 9 \\
\hline$\$ 20,001-\$ 30,000$ & 11 & 12 \\
\hline$\$ 30,001-\$ 50,000$ & 17 & 20 \\
\hline$\$ 50,001-\$ 70,000$ & 12 & 18 \\
\hline$\$ 70,001-\$ 100,000$ & 17 & 19 \\
\hline$\$ 100,001$ or more & 34 & 22 \\
\hline \multicolumn{3}{|l|}{ Other household characteristics } \\
\hline $\begin{array}{l}\text { Completed higher education } \\
\text { (tertiary or post-graduate) }\end{array}$ & 44 & 40 \\
\hline Female & 64 & 51 \\
\hline Not in the Labour Force & 39 & 32 \\
\hline Forest and Bird Member & 8 & - \\
\hline Department of Conservation (DOC) & 3 & - \\
\hline \multicolumn{3}{|l|}{ Volunteer } \\
\hline Tui should be in the choice set & 21 & - \\
\hline Government should pay & 18 & - \\
\hline \multicolumn{3}{|c|}{$\begin{array}{l}\text { Self-rated understanding of CE questions ("10" represents "completely understood" } \\
\text { and "1" represents "did not understand at all") }\end{array}$} \\
\hline-8 to 10 & 47 & - \\
\hline-5 to 7 & 42 & - \\
\hline-1 to 4 & 11 & - \\
\hline
\end{tabular}

a Source: Statistics New Zealand (SNZ).

biodiversity conservation policies. To identify which parameters are random, we tested more than 20 different specifications. Based on this search we identified four parameters as random and these are Bush Falcon 2, Kakabeak 2, Green Gecko 2 and Cost. The three environmental attribute parameters are assumed to have unrestricted triangular distribution while the cost parameter is assumed to have a constrained triangular distribution (as proposed by Hensher and Greene (2003)). ${ }^{7}$ The spreads of the four random parameters are significant at the five percent level indicating taste heterogeneity.

We have also included a random parameter for the status quo effect which is called as "error component". This induces the correlation amongst the two designed alternatives as described in Scarpa et al. (2005). Results indicate a strong correlation between the two designed alternatives as indicated by the coefficient for the error component being positive and significant.

Model estimates suggest strong preference for the protection of native bird species as indicated by significantly positive coefficients for the two improved levels of Brown Kiwi and Bush Falcon. Higher levels of bird abundance are valued more as indicated by higher coefficients for Brown Kiwi 2 and Bush Falcon 2 than the level 1 improvement. However, this does not apply to fish as the coefficient for Kokopu 1 is significantly positive but not so for Kokopu 2 . This demonstrates a pattern of insensitivity to scope which has been previously identified as a potential issue in CV and in CE (Foster and Mourato, 2003; Goldberg and Roosen, 2007; Rolfe and Windle, 2010; Ryan and Wordsworth, 2000). However, Banerjee and Murphy (2005) argued that insensitivity to scope was not a necessary condition for preference consistency. From this perspective, we find our WTP estimates to be valid.

Based on the model specification above, we simulated the conditional means and medians of individual WTP distributions for each of the 209 respondents. A summary of these values is given in Table 4. Median WTP values suggest that the two most valued attribute levels are level 2 increases in Falcon (\$24/year) and Brown Kiwi (\$21/year). We also

\footnotetext{
${ }^{7}$ We have used unrestricted triangular for the environmental attributes to allow the WTP to vary between positive and negative. For example, some people might have a negative preference for geckos which may be regarded as undesirable "creepy crawlies". Constrained triangular distributions are often or primarily used to constrain a random coefficient's variation to a given sign or neighbourhood of values. In our case, instead, we used the unconstrained triangular for the random coefficients because this choice of distribution fit the data better than alternative ones (e.g., normal and log-normal).
}

Table 2

Summary statistics for the three spatial covariates in the OLS panel regression.

\begin{tabular}{|c|c|c|}
\hline $\begin{array}{l}\text { Spatial covariate (Buffer zone } \\
\text { size and range of forested } \\
\text { areas within each zone) }\end{array}$ & $\begin{array}{l}\text { Area of planted } \\
\text { forests within the } \\
\text { radius (hectares) }\end{array}$ & $\begin{array}{l}\text { Number of respondents } \\
\text { (\% of } 115 \text { respondents } \\
\text { with spatial coordinates) }{ }^{\mathrm{a}}\end{array}$ \\
\hline 10-km radius & & $28(24 \%)$ \\
\hline - Average & 3,936 & \\
\hline - Minimum & 17 & \\
\hline - Maximum & 14,000 & \\
\hline Between $10-$ and $50-\mathrm{km}$ radius & & $82(71 \%)$ \\
\hline - Average & 40,175 & \\
\hline - Minimum & 1,900 & \\
\hline - Maximum & 220,000 & \\
\hline Between 50 - and $100-\mathrm{km}$ radius & & $29(25 \%)$ \\
\hline - Average & 62,334 & \\
\hline - Minimum & 6,200 & \\
\hline - Maximum & 770,000 & \\
\hline
\end{tabular}

report the 5th and 95th percentile WTP for more Falcon (\$14 to \$91) and Kiwi ( $\$ 13$ to $\$ 76)$. The above results suggest that higher WTP values have been placed on birds compared to other species. In terms of attributes levels, we find that a level 1 increase in abundance of Kakabeak and the Giant Kokopu were valued at approximately $\$ 8$ and $\$ 9$ a year, respectively. The level 1 increase in Kokopu is valued, while the level 2 increase is not (Table 4). The coefficients for Gecko 1 and Gecko 2 are insignificant. One may argue that this attribute should have been excluded in the investigation. However, Gecko was included because of its importance for wildlife management.

\subsection{WTP Determinants}

We used panel random effects regressions to explain patterns of variation in individual specific WTP of the sample of respondents. In the set of explanatory variables, we included indicator variables for all but one attribute level to avoid the dummy variable trap for the different types of marginal WTP estimates provided by each respondent. We explore the role of socioeconomic characteristics, attitudes and geo-spatial distance of each respondent on WTP values. The estimates for the panel regression model are shown in Table 5 . As some respondents did not report their socio-economic data, the sample size was reduced to 1600 observations. Also as some respondents were not located due to insufficient data, the sample size was further reduced to 1110 observations. ${ }^{8}$

Results from the reduced sample of respondents show a significantly positive coefficient for Higher Education which suggests that being a respondent who completed at least tertiary education positively affects WTP by about NZ $\$ 2.90$ (Table 5). Being part of the labour force contributes to a higher WTP of NZ\$3.60 than those who were not in the labour force (e.g., students, retired, homemakers (such as housewives)). ${ }^{9}$ Results from this sample indicate that being a Department of Conservation volunteer or a Forest and Bird member, had the greatest positive effect on WTP among other characteristics. As expected, a respondent with a "Government Should Pay" attitude would have a WTP lower by NZ\$3.13.

Results from a restricted panel regression model that do not have spatial covariates but with a larger sample size (160 respondents),

\footnotetext{
${ }^{8}$ Despite the reduction in sample size, we have no reason to believe that missing data points on geographical location of residence is correlated with distance to forests, which is our variable of interest. Therefore, we expect our result to maintain validity for the purpose of our discussion.

${ }^{9}$ In New Zealand people not in the labour force (e.g., retired), still pay income taxes. Homemakers and adult students are also required to file (and if needed pay) their income taxes even when they do not have work income in that tax year. In this study, the proportion of respondents who were not in the labour force was higher than the national average. This is often the case in survey research due to the fact that the cost of time of this category of people is lower than that of those in the labour force (e.g., Kaval et al. (2009)).
} 
Table 3

Estimates from RPL panel with error components.

\begin{tabular}{|c|c|c|c|c|c|c|c|}
\hline \multirow[t]{2}{*}{ Item } & \multicolumn{7}{|c|}{ Estimates } \\
\hline & Coeff & Std err & $p$-Value & Assumed distribution & Spread or Std dev of random parameter & Std err & $p$-value \\
\hline Brown Kiwi 1 & 0.898 & 0.137 & $<0.01$ & & & & \\
\hline Brown Kiwi 2 & 1.048 & 0.128 & $<0.01$ & & & & \\
\hline Kokopu 1 & 0.311 & 0.153 & 0.04 & & & & \\
\hline Kokopu 2 & 0.133 & 0.145 & 0.36 & & & & \\
\hline Kakabeak 1 & 0.330 & 0.164 & 0.04 & & & & \\
\hline Kakabeak 2 & 0.324 & 0.161 & 0.04 & Unres Tri & 1.309 & 0.536 & 0.01 \\
\hline Green Gecko 1 & 0.052 & 0.133 & 0.70 & & & & \\
\hline Green Gecko 2 & 0.123 & 0.159 & 0.44 & & 1.486 & 0.553 & 0.01 \\
\hline Bush Falcon 1 & 0.907 & 0.149 & $<0.01$ & & & & \\
\hline Bush Falcon 2 & 1.178 & 0.145 & $<0.01$ & Unres Tri & 1.484 & 0.661 & 0.02 \\
\hline Status Quo (SQ) Indicator & -1.333 & 0.721 & 0.06 & & & & \\
\hline Cost & -0.063 & 0.004 & $<0.01$ & Restricted Tri & 0.063 & 0.004 & $<0.01$ \\
\hline Error component $\left(\sigma_{\varepsilon}\right)$ & & & & Normal & 7.674 & 1.007 & $<0.01$ \\
\hline Log-likelihood & & & & & -992.79 & & \\
\hline Normalised AIC & & & & & 1.091 & & \\
\hline McFadden Pseudo $\mathrm{R}^{2}$ & & & & & 0.512 & & \\
\hline No. of observations & & & & & 1850 & & \\
\hline
\end{tabular}

Note 1: Attributes in italics are random parameters with corresponding spread parameters.

Note 2: Green Gecko 1 serves as the reference attribute level.

show that a respondent who indicated that "Tui Should be in the Choice Task" would be willing to pay $\$ 2.67$ more while a "Female" would pay $\$ 2.42$ more. These coefficient estimates are both statistically significant at the $99 \%$ confidence level in that side regression. However, estimates in Table 5 (model with spatial covariates with 110 respondents), these two coefficients are no longer statistically significant.

In terms of the effects of the spatial zone covariates to WTP, the significantly positive coefficient for the 10-kilometre radius suggested that a respondent who resides within a 10-kilometre radius of a large planted forest would pay $\$ 2.20$ more for a $10 \%$ expansion in forest area with a biodiversity programme. This might indicate a form of use value associated with living within biking distance of a large planted forest. Results also indicate that the WTP of a respondent living within the 10 to 50-kilometre radius would not have a significantly different WTP. A possible reason for this is that people perceived that the potential to benefit from enhanced biodiversity is low as it would likely take a day to visit that forest. A respondent residing within the 50 to100kilometre radius had a slightly higher WTP of $\$ 2.25$ for a $10 \%$ increase in forest area with biodiversity. This might indicate the presence of option-use values to respondents who live further away from planted forests. They would be willing to pay more by knowing that the area of habitat for threatened species would increase even though they are not likely to visit those forests immediately, but maybe some time in the future. However, the estimate for the dummy variable of living "within the $50-100$-kilometre radius" is significant only at the $90 \%$ confidence level and therefore statistically weak compared to the coefficient estimate for the "10-kilometre" zone.

\section{Conclusions and Policy Implications}

Our results from a CE survey conducted on a sample of New Zealand residents indicate that biodiversity enhancement in large planted forests is valued. Native species are appreciated more than exotics in the country, so the value to a greater extent pertains to the increase in abundance of native species, and to a lesser extent the exotic forest landscape. A typical respondent would be willing to pay for such native enhancement via an increase in income tax. The money would be destined to the Department of Conservation which, in coordination with forest companies, would implement the proposed programme to increase the number of threatened species seen or heard in New Zealand planted forests. In terms of policy use of this information, it is important to have a measure of individual variation of WTP to identify its determinants. An understanding of the fact that WTP is higher for those who reside closer to commercial forest may help the calibration of a potential conservation tax.

This study extends previous work by Yao and Kaval (2010) showing that a sample of New Zealanders would pay for biodiversity enhancement on private land. This study demonstrates that even in productive, planted forests, some New Zealanders still value habitat enhancement for threatened native species. The estimated value may be useful not only for future government policy decision making but also to satisfy the growing interest of large corporations to include ecosystem services values in business plans (MEA, 2005; TEEB, 2010; WBCSD, 2011). For instance, the recent UK National Ecosystem Assessment recognises that biodiversity conservation has an economic value that should be

Table 4

Summary of simulated willingness-to-pay ( $\mathrm{n}=209)$. (Individual specific WTPs derived from RPL-EC model from Model 3 in Table 3 ).

\begin{tabular}{|c|c|c|c|c|c|}
\hline & Mean WTP & Median WTP & Std Dev & 5th percentile & 95th percentile \\
\hline Brown Kiwi 1 & 24.18 & 18.07 & 16.78 & 11.42 & 64.79 \\
\hline Brown Kiwi 2 & 28.24 & 21.10 & 19.59 & 13.33 & 75.64 \\
\hline Kokopu 1 & 8.37 & 6.25 & 5.81 & 3.95 & 22.43 \\
\hline Kokopu 2 & NS & NS & NS & NS & NS \\
\hline Kakabeak 1 & 8.89 & 6.64 & 6.12 & 4.19 & 23.80 \\
\hline Kakabeak 2 & 8.37 & 6.05 & 8.59 & 0.75 & 26.51 \\
\hline Green Gecko 1 & NS & NS & NS & $N S$ & NS \\
\hline Green Gecko 2 & NS & NS & NS & NS & NS \\
\hline Bush Falcon 1 & 24.44 & 18.26 & 16.96 & 11.54 & 65.48 \\
\hline Bush Falcon 2 & 31.68 & 23.63 & 23.86 & 13.50 & 91.01 \\
\hline Indicator for SQ & NS & NS & NS & $N S$ & NS \\
\hline
\end{tabular}

Note: NS means the coefficient is not statistically significant at the five percent level. 
Table 5

OLS panel regression model parameter estimates.

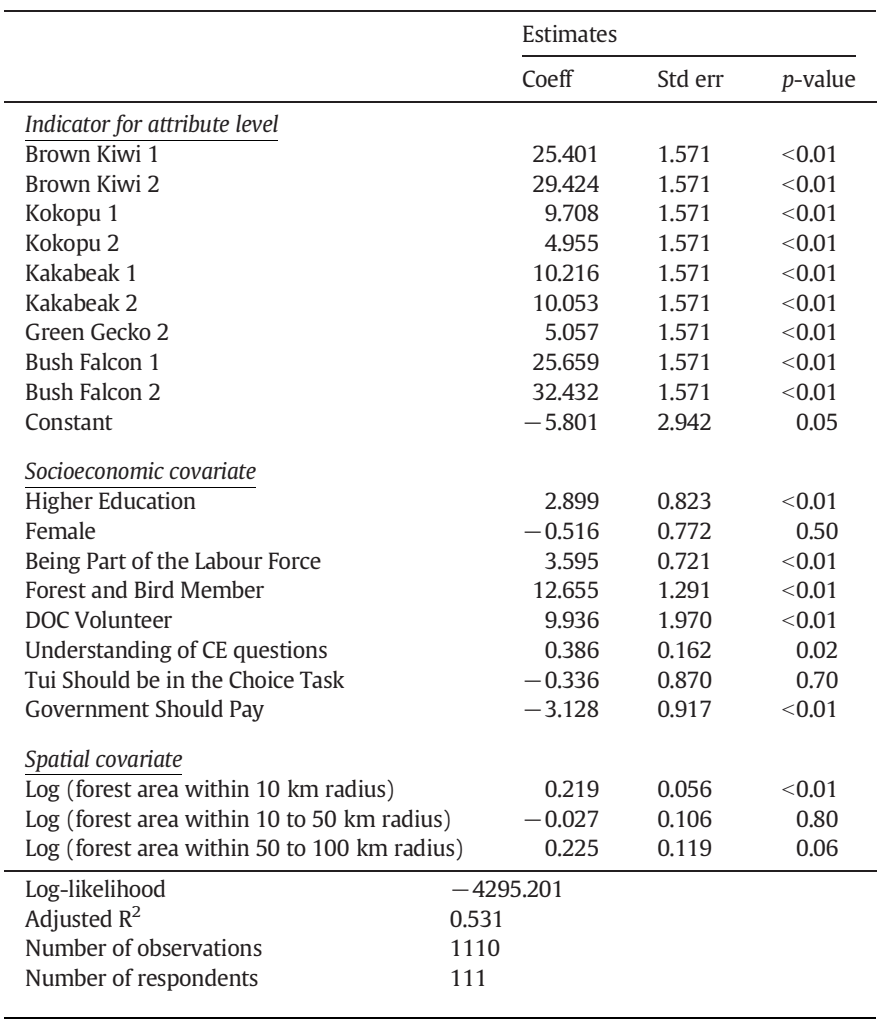

considered in evaluating changes in ecosystems (UKNEA, 2011). In addition, members of the business community have been reported as being keen to work with policy makers to ensure that biodiversity and ecosystem values be integrated into policy and regulation of productive activities (WBCSD, 2011). Despite its obvious limitation in response rate, this study complements results from previous studies that indicate that although forest companies would need to incur a significant increase in cost to support biodiversity enhancement (e.g., Raunikar and Buongiorno, 2006; Yao et al., 2012), the general public would be willing to financially support such an initiative from this commercially productive ecosystem. Also, given the small sample size, our results should not be aggregated over the total New Zealand population.

While previous studies separately identified the socioeconomic and spatial (distance) determinants of WTP (e.g., Campbell, 2007 socioeconomic effects; Schaafsma et al., 2012 - socio-demographic characteristics and directional distance effects), this study identified the effects of both groups of determinants and other factors. This study extends previous work by explaining the effects of socio demographic characteristics, affiliation and attitudes on WTP and found results similar to those reported in previous studies (e.g., Campbell (2007), Scarpa et al. (2011) and Rosenberger et al. (2012)). We also examined the impact of distance from place of residence of respondents to their closest large planted forests and found evidence that respondents tend to have a higher WTP when they live closer to the environmental good which might suggest a type of use value. Future studies may cast additional light to the finding of higher WTP by those who are more likely to use the resource. For example, the impact of a proposed programme on the use, option use and non-use values of biodiversity enhancement through distance effects could be explored, while also accounting for the effect of socio economic characteristics on WTP.

Future investigations should explore whether or not estimates of WTP amounts would support the cost of attaining target outcomes (e.g., increasing falcon sightings in the Kaingaroa Forests from oneout-of-eight to five-out-of-eight drives). The New Zealand Department of Conservation currently supports the conservation of key threatened species (e.g., brown kiwi) on public conservation land in cooperation with the private sector (DOC, 2012). A future study could, for example, examine mechanisms that would facilitate conservation of such species on private land. Such study may follow the one conducted by Horne (2008) that evaluated different biodiversity enhancement schemes such as compulsory land acquisition and voluntary conservation. Perhaps it could compare existing schemes such as those already established in New Zealand, e.g., Operation Nest Egg (Colbourne et al., 2005) and with those already established elsewhere, such as species conservation banking (Fox and Nino-Murcia, 2005).

\section{Acknowledgements}

We would like to thank the staff members of Scion, forest companies, conservation organisations, focus group participants and forest ecologists who helped in the development and implementation of this research; Ruth Falshaw for editorial assistance; and the anonymous reviewers for their valuable comments and suggestions. We also extend our appreciation to the survey respondents for taking the time to participate in the economic valuation survey. This research was made possible by funding provided by Scion and Future Forest Research.

\section{Appendix A}

Example of the cheap talk script presented to the survey respondents.

We are now going to present you with a number of choice situations. These describe the outcomes of conservation policies that could be undertaken by the Department of Conservation in partnership with concerned organisations (e.g., forest corporations). Ecologists suggest that over the next five years, planted forests could be managed to provide better habitat for threatened species. These species include the above four threatened animals and one plant species. For each choice situation we present you, we will ask you to select the alternative with the conservation outcomes you prefer. Some outcomes will require a contribution to the Department of Conservation through an additional amount in your annual income tax for five years. In each choice situation, there is also the possibility of taking no conservation action ("Current Condition") and paying no money.

Please remember to consider the payment as if it was real and give honest answers so as to inform conservation policy.

\section{Appendix B}

Estimates of multinomial logit model coefficients from the pilot sample of 35 respondents.

\begin{tabular}{|c|c|c|c|c|}
\hline & Coefficient & Standard Error & T-ratio & P-value \\
\hline Brown Kiwi 1 & 0.462 & 0.252 & 1.832 & 0.067 \\
\hline Brown Kiwi 2 & 0.591 & 0.251 & 2.354 & 0.019 \\
\hline Kokopu 1 & 0.242 & 0.241 & 1.002 & 0.316 \\
\hline Kokopu 2 & 0.286 & 0.248 & 1.155 & 0.248 \\
\hline Kakabeak 1 & 0.335 & 0.233 & 1.441 & 0.150 \\
\hline Kakabeak 2 & 0.112 & 0.251 & 0.446 & 0.655 \\
\hline Green Gecko 1 & 0.190 & 0.246 & 0.771 & 0.441 \\
\hline Green Gecko 2 & 0.549 & 0.241 & 2.278 & 0.023 \\
\hline Bush Falcon 1 & 0.550 & 0.253 & 2.174 & 0.030 \\
\hline Bush Falcon 2 & 0.706 & 0.246 & 2.865 & 0.004 \\
\hline Cost & -0.021 & 0.004 & -5.136 & $<0.001$ \\
\hline Indicator for Status Quo & 0.876 & 0.413 & 2.122 & 0.034 \\
\hline \multicolumn{2}{|l|}{ Log-likelihood value } & \multicolumn{3}{|c|}{-324.473} \\
\hline \multicolumn{2}{|l|}{ Pseudo Rho ${ }^{2}$} & \multicolumn{3}{|c|}{0.078} \\
\hline \multicolumn{2}{|l|}{ Adj Pseudo Rho ${ }^{2}$} & \multicolumn{3}{|c|}{0.060} \\
\hline \multicolumn{2}{|c|}{ Number of choice observations } & \multicolumn{3}{|c|}{314} \\
\hline \multicolumn{2}{|c|}{ Number of respondents } & \multicolumn{3}{|c|}{35} \\
\hline
\end{tabular}




\section{References}

Alavalapati, J.R.R., Stainback, G.A., Carter, D.R., 2002. Restoration of the longleaf pine ecosystem on private lands in the US South: an ecological economic analysis. Ecol. Econ. 40, 411-419.

Axsen, J., Mountain, D.C., Jaccard, M., 2009. Combining stated and revealed choice research to simulate the neighbor effect: the case of hybrid-electric vehicles. Resour. Energy Econ. 31, 221-238.

Banerjee, S., Murphy, J.H., 2005. The scope test revisited. Appl. Econ. Lett. 12, 613-617.

Bateman, I.J., Langford, I.H., Nishikawa, N., Lake, I., 2000. The Axford Debate Revisited: A Case Study Illustrating Different Approaches to the Aggregation of Benefits Data. J. Environ. Plan. Manag. 43, 291-302.

Bateman, I.J., Day, B.H., Georgiou, S., Lake, I., 2006. The aggregation of environmental benefit values: welfare measures, distance decay and total WTP. Ecol. Econ. 60, 450-460.

Bauhus, J., Pokorny, B., Van der Meer, P., Kanowski, P.J., Kanninen, M., 2010. Ecosystem goods and services-the key for sustainable plantations, Ecosystem Goods and Services from Plantation Forests. Earthscan, London, UK.

Boxall, P.C., Macnab, B., 2000. Exploring the preferences of wildlife recreationists for features of boreal forest management: a choice experiment approach. Can. J. For. Res. 30, 1931-1941.

Boxall, P.C., Adamowicz, W.L., Swait, J., Williams, M., Louviere, J., 1996a. A comparison of stated preference methods for environmental valuation. Ecol. Econ. 18, 243-253.

Boxall, P.C., Watson, D.O., Englin, J., 1996b. Backcountry recreationists' valuation of forest and park management features in wilderness parks of the western Canadian Shield. Can. J. For. Res. 26, 982-990.

Brockerhoff, E.G., Jactel, H., Parrotta, J.A., Quine, C.P., Sayer, J., 2008. Plantation forests and biodiversity: oxymoron or opportunity? Biodivers. Conserv. 17, 925-951.

Brouwer, R., Martin-Ortega, J., 2012. Modeling self-censoring of polluter pays protest votes in stated preference research to support resource damage estimations in environmental liability. Resource and Energy Economics 34, 151-166.

Burgess, L., Street, D.J., 2005. Optimal designs for choice experiments with asymmetric attributes. J. Stat. Plan. Infer. 134, 288-301.

CAG (Controller, Auditor General), 2012. Department of Conservation: Prioritising and Partnering to Manage Biodiversity. Performance Audit ReportOffice of the AuditorGeneral, Wellington (84 pp.).

Cameron, T.A., 2006. Directional heterogeneity in distance profiles in hedonic property value models. J. Environ. Econ. Manag. 51 (1), 26-45.

Cameron, T.A., DeShazo, J.R., Johnson, E., 2011. Scenario adjustment in stated preference research. J. Choice Model. 4, 9-43.

Campbell, D., 2007. Willingness to pay for rural landscape improvements: combining mixed logit and random-effects models. J. Agric. Econ. 58, 467-483.

Campbell, D., Scarpa, R., Hutchinson, W., 2008. Assessing the spatial dependence of welfare estimates obtained from discrete choice experiments. Lett. Spat. Resour. Sci. 1, 117-126.

Campbell, D., Hutchinson, W.G., Scarpa, R., 2009. Using choice experiments to explore the spatial distribution of willingness to pay for rural landscape improvements. Environ. Plan. A 41, 97-111.

Chen, T.T., Chung, K.P., Huang, H.C., Man, L.N., Lai, M.S., 2010. Using discrete choice experiment to elicit doctors' preferences for the report card design of diabetes care in Taiwan-a pilot study. J. Eval. Clin. Pract. 16, 14-20.

ChoiceMetrics, 2011. Ngene 1.1 User manual and reference guide, choice-metrics. www. choice-metrics.com.

Christie, M., Hanley, N., Warren, J., Murphy, K., Wright, R., Hyde, T., 2006. Valuing the diversity of biodiversity. Ecol. Econ. 58 (2), 304-317.

Christie, M., Hanley, N., Hynes, S., 2007. Valuing enhancements to forest recreation using choice experiments and contingent behaviour methods. J. For. Econ. 13, 75-102.

Colbourne, R., Bassett, S., Billing, T., McCormick, H., McLennan, J., Nelson, A., Robertson, H., 2005. The Development of Operation Nest Egg as a Tool in the Conservation Management of kiwi. Science and Technical Publishing, Department of Conservation, Wellington (24 pp.).

Concu, G.B., 2007. Investigating distance effects on environmental values: a choice modelling approach. Aust. J. Agric. Resour. Econ. 51, 175-194.

Cummings, R.G., Taylor, L.O., 1999. Unbiased value estimates for environmental goods: a cheap talk design for the contingent valuation method. Am. Econ. Rev. 89, 649-665.

Dhakal, B., Yao, R., Turner, J.A., Barnard, T., 2012. Recreational users' willingness to pay and preferences for changes in planted forest features. For. Policy Econ. 17, 34-44.

DOC (Department of Conservation), 2010. Department of Conservation Annual Report. Department of Conservation, Wellington 127.

DOC (Department of Conservation), 2012. Department of Conservation Annual Report: For the Year Ended 30 June 2012. Department of Conservation, Wellington 116.

DOI (Department of the Interior), 1994. Proposed rules for valuing environmental damages. Fed. Regist. 59 (85), 23098-23111.

Dyck, B., 2003. Benefits of planted forests: social, ecological and economic. UNFF Intersessional Experts Meeting on the Role of Planted Forests in Sustainable Forest Management, Wellington.

FAO, 2010. Global Forest Resources Assessment 2010-Key Findings. Food and Agriculture Organisation, Rome.

FAO, 2012a. Planted Forests. Food and Agriculture Organization of the United Nations. Accessed on 16 April 2013 at http://www.fao.org/forestry/plantedforests/en/.

FAO, 2012b. State of the World's Forests 2012. Food and Agriculture Organization of the United Nations, Rome.

Foster, V., Mourato, S., 2003. Elicitation format and sensitivity to scope: do contingent valuation and choice experiments give the same results? Environ. Resour. Econ. 24, 141-160.

Fox, J., Nino-murcia, A., 2005. Status of species conservation banking in the United States. Conserv. Biol. 19 (4), 996-1007.
Freeman, A.M., 1993. The Measurement of Environmental and Resource Values: Theory and Methods. Resources for the Future, Washington, D.C.

Garrod, G.D., Willis, K.G., 1997. The non-use benefits of enhancing forest biodiversity: a contingent ranking study. Ecol. Econ. 21, 45-61.

Garrod, G.D., Scarpa, R., Willis, K.G., 2002. Estimating the benefits of traffic calming on through routes: a choice experiment approach. J. Transp. Econ. Policy 36, 211-231.

Getis, A., Ord, K., 1992. The analysis of spatial association by use of distance statistics. Geogr. Anal. 24, 189-206.

Goldberg, I., Roosen, J., 2007. Scope insensitivity in health risk reduction studies: a comparison of choice experiments and the contingent valuation method for valuing safer food. J. Risk Uncertain. 34, 123-144.

Haaijer, M.E., 1999. Modeling conjoint choice experiments with the probit model EconomicsUniversity of Groningen, Groningen.

Haaijer, M.E., Kamakura, W.A., Wedel, M., 2001. The no-choice alternative in conjoint choice. Int. J. Mark. Res. 43, 93-106.

Hanley, N., Willis, K.G., Powe, N., Anderson, M., 2002. Valuing the Benefits of Biodiversity in Forests, Social \& Environmental Benefits of Forestry Phase 2. Centre for Research in Environmental Appraisal \& Management, University of Newcastle, Edinburgh.

Hanley, N., Schläpfer, F., Spurgeon, J., 2003. Aggregating the benefits of environmenta improvements: distance-decay functions for use and non-use values. J. Environ. Manag. 68, 297-304.

Harrison, G.W., 2006. Making choice studies incentive compatible. In: Kanninen, B. (Ed.) Valuing Environmental Amenities Using Stated Choice Studies: A Common Sense Guide to Theory and Practice. Kluwer, Boston, pp. 65-108.

Hensher, D.A., 2008. Empirical approaches to combining revealed and stated preference data: some recent developments with reference to urban mode choice. Res. Transp. Econ. 23, 23-29.

Hensher, D.A., Greene, W.H., 2003. The mixed logit model: the state of practice Transportation 30, 133-176.

Herriges, J.A., Phaneuf, D.J., 2002. Inducing patterns of correlation and substitution in repeated logit models of recreation demand. Am. J. Agric. Econ. 84, 1076-1090.

Hess, S., Rose, J., 2009. Should reference alternatives in pivot design SC surveys be treated differently? Environ. Resour. Econ. 42, 297-317.

Horne, P., 2008. Use of choice experiments in assessing the role of policy instruments in social acceptability of forest biodiversity conservation in Southern Finland. In: Birol, E., Koundouri, P. (Eds.), Choice Experiments Informing Environmental Policy: A European Perspective. Edward Elgar, Cheltenham, UK; Northampton, MA pp. 178-197.

Johnston, R.J., Roheim, C.A., 2006. A battle of taste and environmental convictions for ecolabeled seafood: a contingent ranking experiment. J. Agric. Resour. Econ. 31 283-300.

Johnston, R.J., Ramachandran, M., Schultz, E.T., Segerson, K., Besedin, E.Y., 2011. Characterizing spatial pattern in ecosystem service values when distance decay doesn't apply: choice experiments and local indicators of spatial association. Agricultural \& Applied Economics Association's 2011 AAEA \& NAREA Joint Annual Meeting, Pittsburgh, Pennsylvania.

Jukes, M.R., Peace, A.J., Ferris, R., 2001. Carabid beetle communities associated with coniferous plantations in Britain: the influence of site, ground vegetation and stand structure. For. Ecol. Manag. 148, 271-286.

Kaval, P., Yao, R., Scrimgeour, F., 2009. The economic value of biodiversity in New Zealand: results from a household survey. Working Paper in Economics 09/05. Department of Economics, University of Waikato, Hamilton, New Zealand.

Kerr, G.N., Sharp, B.M.H., 2010. Choice experiments adaptive design benefits: a case study. Aust. J. Agric. Resour. Econ. 54, 407-420.

Landry, C.E., List, J.A., 2007. Using ex ante approaches to obtain credible signals for value in contingent markets: evidence from the field. Am. J. Agric. Econ. 89 (2), 420-429.

Loomis, J.B., 1996. How large is the extent of the market for public goods: evidence from a nationwide contingent valuation survey. Appl. Econ. 28, 779-782.

Matta, J.R., Alavalapati, J.R.R., Stainback, G.A., 2009. Effect of conserving habitat for biodiversity on optimal management of non-industrial private forests in Florida. J. For. Econ. 15, 223-235.

Maunder, C. 2008. Face to face personal communication with Colin Maunder of Timberlands Ltd., Rotorua, New Zealand.

Maunder, C., Shaw, W., Pierce, R., 2005. Indigenous biodiversity and land use - what do exotic plantation forests contribute? N. Z. J. For. 49, 20-26.

Mazur, K., Bennett, J., 2009. Location differences in communities' preferences for environmental improvements in selected NSW catchments: a choice modelling approach. Paper Presented at the 54st Annual Conference of the Australian Agricultura and Resource Economics Society, Cairns, Australia, 10-13 February 2009.

McFadden, D., Train, K.E., 2000. Mixed MNL models for discrete response. J. Appl. Econ. 15 447-470.

MEA (Millennium Ecosystem Assessment), 2005. Ecosystems and human well-being: Biodiversity synthesis. World Resources Institute, Washington DC.

Meyerhoff, J.R., Liebe, U., Hartje, V., 2009. Benefits of biodiversity enhancement of natureoriented silviculture: evidence from two choice experiments in Germany. J. For. Econ. $15,37-58$

Ministry for the Environment, 2000a. Bio-what? Addressing the Effects of Private Land Management on Indigenous Biodiversity. Ministry for the Environment, Wellington.

Ministry for the Environment, 2000b. The New Zealand Biodiversity Strategy. Ministry for the Environment, Wellington.

Ministry for the Environment, 2011. The New Zealand Land Cover Database. Available online at http://www.mfe.govt.nz/issues/land/land-cover-dbase/index.html.

Morse-Jones, S., Bateman, I.J., Kontoleon, A., Ferrini, S., Burgess, N.D., Turner, R.K., 2012 Stated preferences for tropical wildlife conservation amongst distant beneficiaries: charisma, endemism, scope and substitution effects. Ecol. Econ. 78, 9-18. 
Mozumder, P., Berrens, R.P., 2007. Investigating hypothetical bias: induced-value tests of the referendum voting mechanism with uncertainty. Appl. Econ. Lett. 14 (10) 705-709.

MPI (Ministry for Primary Industries), 2012. National Exotic Forest Description as of 1 April 2012. Ministry for Primary Industries, Wellington (76 pp.).

NZFOA (New Zealand Forest Owners Association), 2011. New Zealand Plantation Forest Industry. New Zealand Forest Owners Association, Wellington.

Pawson, S., 2005. Natives in a pine forest. N. Z. Geogr. 78, 79-93.

Pawson, S.M., Ecroyd, C.E., Seaton, R., Shaw, W.B., Brockerhoff, E.G., 2010. New Zealand's exotic plantation forests as habitats for threatened indigenous species. N. Z. J. Ecol. 34, 342-355.

Raunikar, R., Buongiorno, J., 2006. Willingness to pay for forest amenities: the case of non-industrial owners in the south central United States. Ecol. Econ. 56, 132-143.

Revelt, D., Train, K.E., 1998. Mixed logit with repeated choices: households' choices of appliance efficiency level. Rev. Econ. Stat. 80, 647-657.

Rolfe, J., Windle, J., 2010. Testing for geographic scope and scale effects with choice modelling: application to the Great Barrier Reef. Environmental Economics Research Hub Research Reports 1069.Environmental Economics Research Hub, Crawford School of Public Policy, The Australian National University.

Rolfe, J., Windle, J., 2012. Distance decay functions for iconic assets: assessing national values to protect the health of the Great Barrier Reef in Australia. Environ. Resour. Econ. 53, 347-365.

Rose, J.M., Bain, S., Bliemer, M.C.J., 2011. Experimental design strategies for stated preference studies dealing with non-market goods. In: Bennett, J. (Ed.), International Handbook on Non-Marketed Environmental Valuation. Edward Elgar, Cheltenham.

Rosenberger, R.S., Needham, M.D., Morzillo, A.T., Moehrke, C., 2012. Attitudes, willingness to pay, and stated values for recreation use fees at an urban proximate forest. J. For. Econ. 18, 271-281.

Ryan, M., Wordsworth, S., 2000. Sensitivity of willingness to pay estimates to the level of attributes in discrete choice experiments. Scott. J. Polit. Econ. 47 (5), 504-524.

Samuelson, W., Zeckhauser, R., 1988. Status-quo bias in decision-making. J. Risk Uncertain. 24, 7-59.

Scarpa, R., Rose, J.M., 2008. Design efficiency for non-market valuation with choice modelling: how to measure it, what to report and why. Aust. J. Agric. Resour. Econ. 52, 253-282.

Scarpa, R., Thiene, M., 2005. Destination choice models for rock climbing in the northeastern Alps: a latent-class approach based on intensity of preferences. Land Econ. 81 (3), 426-444.

Scarpa, R., Chilton, S.M., Hutchinson, W.G., Buongiorno, J., 2000. Valuing the recreational benefits from the creation of nature reserves in Irish forests. Ecol. Econ. 33, 237-250.

Scarpa, R. Ferrini, S., Willis, K., 2005. Performance of error component models for status-quo effects in choice experiments. In: Scarpa, R., Alberini, A. (Eds.), Applications of Simulation Methods in Environmental and Resource Economics. Springer, Dordrecht, The Netherlands.

Scarpa, R., Campbell, D., Hutchinson, W.G., 2007. Benefit estimates for landscape improvements: sequential Bayesian design and respondents' rationality in a choice experiments. Land Econ. 83, 617-634.

Scarpa, R., Notaro, S., Louviere, J., Raffaelli, R., 2011. Exploring scale effects of best/worst rank ordered choice data to estimate benefits of tourism in Alpine grazing commons. Am. J. Agric. Econ. 93, 813-828.

Schaafsma, M., Brouwer, R., Rose, J., 2012. Directional heterogeneity in WTP models for environmental valuation. Ecol. Econ. 79, 21-31.

Seaton, R., 2007. The ecological requirements of the New Zealand (Falco novaeseelandiae) in plantation forestry. (PhD thesis in Zoology) Massey University, Palmerston North, New Zealand.
Seaton, R., Holland, J.D., Minot, E.O., Springett, B.P., 2009. Breeding success of New Zealand falcons (Falco novaeseelandiae) in a pine plantation. N. Z. J. Ecol. 33, 32-39.

Seaton, R., Minot, E.O., Holland, J.D., 2010. Nest-site selection of New Zealand Falcons (Falco novaeseelandiae) in plantation forests and the implications of this to forestry management. Emu 110, 316-323.

SNZ (Statistics New Zealand), 2011. Browse for statistics. Statistics New Zealand, Wellington.

Statistics New Zealand, Undated. New Zealand: An Urban/Rural Profile Update (Updated Data Tables: People). Available online at http://www.stats.govt.nz/browse_for_stats/ people_and_communities/Geographic-areas/urban-rural-profile-update.aspx.

Stewart, D., Hyde, N., 2004. New Zealand falcons (Falco novaeseelandiae) nesting in exotic plantations. Notornis 51, 119-121.

Sutherland, R.J., Walsh, R.G., 1985. Effect of distance on the preservation value of water quality. Land Econ. 61, 281-291.

Tait, P., Baskaran, R., Cullen, R., Bicknell, K., 2012. Non-market valuation of water quality: addressing spatially heterogeneous preferences using GIS and a random parameter logit model. Ecol. Econ. 75, 15-21.

TEEB, 2010. The Economics of Ecosystems and Biodiversity: Mainstreaming the Economics of Nature: A Synthesis of the Approach, Conclusions and Recommendations of TEEB.

Train, K.E., 2009. Discrete Choice Methods with Simulation. Cambridge University Press, New York.

Train, K., Weeks, M., 2005. Discrete choice models in preference space and willing-to-pay space. In: Scarpa, R., Alberini, A. (Eds.), Applications of Simulation Methods in Environmental and Resource Economics. Springer, Dordrecht, The Netherlands, pp. 1-16.

Travisi, C.M., Nijkamp, P., 2008. Valuing environmental and health risk in agriculture: a choice experiment approach to pesticides in Italy. Ecol. Econ. 67 (4), 598-607.

UKNEA (UK National Ecosystem Assessment), 2011. The UK National Ecosystem Assessment: Synthesis of the Key Findings. UNEP-WCMC, Cambridge.

UNCED, 1992. The Forest Principles. Agenda 21. Clause 6d, Chapter 11. Rio de Janeiro, Brazil, United Nations Conference on Environment and Development.World Business Council for Sustainable Development (WBCSD).

von Haefen, R.H., 2003. Incorporating observed choice into the construction of welfare measures from random utility models. J. Environ. Econ. Manag. 45 (2), 145-165.

Vossler, C.A., Doyon, M., Rondeau, D., 2012. Truth in consequentiality: theory and field evidence on discrete choice experiments. Am. Econ. J. 4 (4), 141-171.

WBCSD, 2011. Guide to Corporate Ecosystem Valuation: A Framework for Improving Corporate Decision-making. World Business Council for Sustainable Development (WBCSD), Geneva, Switzerland.

Weir, P., 2010. Face to Face Personal Communication. Wellington, New Zealand.

Whitehead, J., Haab, T., Huang, J.C., 2011. Preference Data for Environmental Valuation: Combining Revealed and Stated Preference Approaches. Routledge, New York.

Whittam, R.M., McCracken, J.D., Francis, C.M., Gartshore, M.E., 2002. The effects of selective logging on nest-site selection and productivity of hooded warblers (Wilsonia citrina) in Canada. Can. J. Zool. 80, 644-654.

Wordsworth, S., Ryan, M., Skåtun, D., Waugh, N., 2006. Women's preferences for cervical cancer screening: a study using a discrete choice experiment. Int. J. Technol. Assess, Health Care 22, 344-350.

Yao, R.T., 2012. The non-market value of biodiversity enhancement in New Zealand's planted forests. Unpublished PhD thesis. Department of Economics, University of Waikato, New Zealand.

Yao, R.T., Kaval, P., 2010. Valuing biodiversity enhancement in New Zealand. Int. J. Ecol. Econ. Stat. 16, 26-42.

Yao, R.T., Barry, L.E., Harrison, D.R., Seaton, R., 2012. A mechanism for enhancing biodiversity in New Zealand. Technical Report. Future Forest Research, Rotorua, New Zealand.

Yao, R.T., Barry, L.E., Wakelin, S.J., Harrison, D.R., Magnard, L.A., Payn, T.W., 2013. Planted forests. In: Dymond, J.R. (Ed.), Ecosystem Services in New Zealand-Conditions and Trends. Manaaki Whenua Press, Lincoln, New Zealand, pp. 62-78. 